\title{
Strony internetowe sklepów komputerowych jako źródło ukraińskiego słownictwa informatycznego
}

Terminologia informatyczna czy też szerzej słownictwo informatyczne ${ }^{1}$ jest obecne w ukraińskiej przestrzeni językowej od wielu dekad. Jego początków należy upatrywać w latach 60.-70. minionego wieku (Jóźwikiewicz 2013a: 57). Jednakże o znaczącym rozwoju tej warstwy leksykalnej mówić można dopiero w odniesieniu do ostatnich dziesięciu, piętnastu lat, co ma bezpośredni związek z postępującą $w$ bardzo szybkim tempie informatyzacją i niemal powszechnym dostępem do najnowszych technologii (komputerów PC, tabletów, mobilnego Internetu, gadżetów z dziedziny $\mathrm{IT}^{2}$ i telekomunikacji itd.). Procesom tym towarzyszy nie tylko stały wzrost jakości usług teleinformatycznych czy ich różnorodności, ale właśnie nad wyraz szybka ewolucja zasobów leksykalnych obsługujących ten niezwykle istotny i, jak się wydaje, nieodzowny dla współczesnego człowieka obszar jego egzystencji.

Na przestrzeni minionych kilkunastu lat ukazało się wiele publikacji, których autorzy skupiali się na różnych aspektach związanych z funkcjonowaniem ukraińskiego słownictwa informatycznego (Jóźwikiewicz 2013b: 33-40). Nie można przy tym pominąc prac, które kodyfikują i utrwalają stan słownictwa $\mathrm{w}$ danym momencie - liczba ukraińskojęzycznych słowników terminologii informatycznej (Jóźwikiewicz 2014: 179-188) jest tu znacząca, jeśli weźmiemy pod uwagę, iż ukraiński segment informatyczny ma o wiele silniejszego konkurenta w postaci potężnego rynku rosyjskiego.

1 Określenie „słownictwo informatyczne” jest bez wątpienia pojęciem szerszym. Obejmuje ono nie tylko zasoby już skodyfikowane (T. jest częścią słownictwa [...] - Encyklopedia 1995: 556), lecz także te określenia, których w żaden sposób nie można zaliczyć do oficjalnych, sformalizowanych; a jednak niezaprzeczalnie odgrywają one istotną rolę w świecie IT.

2 IT (ang. information technology) — technologia informacyjna. 
Badacze zajmujący się problematyką języka technologii informacyjnych na gruncie języka ukraińskiego opierają się na wielu źródłach, wyraźnie ze sobą powiązanych, jednakże zawsze niosących ze sobą pewną dozę odmienności i oryginalności. Do najbardziej popularnych materiałów źródłowych, z których częstokroć korzystają uczeni chcący zmierzyć się z problematyką języka ukraińskiego w obszarze IT, zaliczyć należy m.in. warstwę tekstową pakietów biurowych Microsoft Office $e^{3}$ i systemów operacyjnych Windows $^{4}$, socjolekt informatyczny ${ }^{5}$, historię ukraińskiej informatyki ${ }^{6}$ czy kwestie związane z językiem Internetu ${ }^{7}$. Obszarem do tej pory sukcesywnie pomijanym jest wyizolowana i specyficzna sfera zasobów internetowych - strony ukraińskich sklepów komputerowych. Właśnie one, a dokładniej ich warstwa słowna, będą obiektem dociekań w proponowanym artykule.

Handel elektroniczny (ang. e-commerce) w początkowej fazie swego istnienia, a więc już we wczesnych latach 80 . minionego wieku, opierał się przede wszystkim na elektronicznej wymianie informacji pomiędzy przedsiębiorstwami ${ }^{8}$. W obecnym kształcie zasadza się on głównie na relacjach pomiędzy przedsiębiorstwem a klientem ${ }^{9}$, i zarówno w Stanach Zjednoczonych, jak i w Europie z powodzeniem funkcjonuje od końca lat 90 . Transakcje handlowe z wykorzystaniem drogi elektronicznej za pośrednictwem sklepów internetowych zawierane są na Ukrainie od mniej więcej 10-12 lat. Obecnie działa tam 8 tys. sklepów internetowych ${ }^{10}$, z czego ok. 300 notuje względnie duże obroty towarem. Wśród najbardziej aktywnych i dobrze prosperujących sklepów wykorzystujących świat wirtualny do celów handlowych znajdują się te oferujące sprzęt elektroniczny, w tym sprzęt komputerowy.

Switłana Pyrih stwierdza, że sprzedaż sprzętu AGD oraz elektroniki stanowi niemal połowę dochodu przypadającego na sklepy internetowe (Пиріг 2014: 164-170), a sprzęt komputerowy należy do towarów kupowanych najczęściej. Biorąc pod uwagę fakt, że ten rodzaj handlu na Ukrainie z roku na rok zyskuje na popularności (Пиріг 2014: 167-168), należy podkreślić, że sklepy oferujące to-

3 Zob. m.in. (Рожанківський 2004: 12-17); (Кубайчук, Мейнарович 2003).

4 Zob. m.in. (Григорович 2007: 106-109); (Онищенко 2008: 220-223).

5 Zob. m.in. (Щур 2001: 10); (Щур 2003: 135-143); (Щур 2004a: 209-212); (Щур 2004b: 270-273); (Федорів 2003: 32-43).

6 Zob. m.in. (Іваненко 2011: 70-74); (Симоненко 2003: 169-174); (Стишов 1999: 7-21); (Хоменко 1998); (Хоменко 2000).

7 Zob. m.in. (Рудик 2006); (Недюха 2007); (Стрельбіцька 2005: 33-38); (Зимовець 2009: 108-115).

${ }^{8}$ EDI (ang. Electronic Data Interchange) - wymiana informacji o charakterze gospodarczym pomiędzy systemami informatycznymi przy wykorzystaniu standardowych formatów komunikatów, http://www.edibasics.com/what-is-edi/ (dostęp: 31.05.2015).

9 B2C (ang. business-to-consumer) — relacje między firmą a klientem końcowym; ich inicjatorem jest firma, a odbywają się one głównie za pośrednictwem Internetu, http://www.inc.com/ encyclopedia/business-to-consumer.html (dostęp: 31.05.2015).

10 Dane za 2012 r. Zob. (Пиріг 2014: 168). 
wary $\mathrm{z}$ dziedziny informatyki pozostające $\mathrm{w}$ awangardzie tego rodzaju sprzedaży odgrywają tu niebagatelną rolę nie tylko stricte handlową, ale w pewnym sensie nawet opiniotwórczą. Ze względu na swą mocną pozycję na ukraińskim e-rynku stają się one, w większości przypadków zupełnie bezwiednie, swego rodzaju popularyzatorami słownictwa pojawiającego się na ich stronach internetowych. Wszelkie nowości w sferze IT w normalnych warunkach funkcjonowania mediów opisywane są np. w prasie informatycznej. Na Ukrainie, gdzie ukraińskojęzyczne czasopisma komputerowe de facto nie istnieją, nowe pojęcia z dziedziny informatyki niejednokrotnie po raz pierwszy pojawiają się właśnie na stronach sklepów internetowych. Wydaje się, iż jest to wystarczający powód do tego, by zwrócić na nie baczniejszą uwagę, a powinni to uczynić zwłaszcza ci, którzy zajmują się problematyką funkcjonowania ukraińskiego słownictwa informatycznego czy też terminologii w znaczeniu ogólnym.

Istotną kwestią (podobnie w przypadku nieistniejącej ukraińskojęzycznej prasy informatycznej czy sporadycznych publikacji z dziedziny IT w języku ukraińskim) dotyczącą ukraińskich stron sklepów oferujących nabywcom akcesoria i sprzęt komputerowy jest ich strona językowa. Wiele z nich posiada jedynie wariant rosyjskojęzyczny, o czym można się przekonać korzystając z którejkolwiek przeglądarki internetowej bądź przeglądając ukraińskie portale i katalogi poświęcone zagadnieniom informatycznym. Funkcjonowanie stron dwujęzycznych, z opcją wyboru języka komunikatów należy raczej do rzadkości ${ }^{11}$. Dodatkowym problemem jest obecność języka rosyjskiego na wydawałoby się ukraińskich stronach $w_{w w}{ }^{12}$; funkcjonowanie na nich języka angielskiego, choć czasem rażące, może być poniekąd usprawiedliwione choćby pochodzeniem opisów poszczególnych produktów.

Pomimo tych przeszkód, ukraińskojęzycznych stron www proponujących klientom produkty IT jest w przestrzeni wirtualnej dość dużo $\left(H i m \phi a^{13}\right.$, Diawest $^{14}$, Деріс ${ }^{15}$, МедіаМаркет ${ }^{16}$, Клік $^{17}{ }^{\mathrm{i}}$ wiele innych ${ }^{18}$ ). Są one nie tylko liczne,

11 Sytuacja ta związana jest nie tylko z czasochłonnością tłumaczenia nazw setek czy nawet tysięcy produktów i ich ciągłą aktualizacją, ale po prostu z kosztami takich działań. Do niewielu wyjątków należy tu np. witryna sklepu Альфа.КОМ; zob. alfakom.com.ua/ua/ (dostęp: 22.05.2015).

12 Zob. np. http://nimpha.com.ua/shop/cat/350-gotovie-konfyguracyy-nymfa (dostęp: 22.05.2015).

13 http://www.nimpha.com.ua/ (dostęp: 22.05.2015).

$14 \mathrm{http}: / /$ www.diawest.com/ (dostęp: 22.05.2015).

15 http://defis.lviv.ua/ (dostęp: 22.05.2015).

$16 \mathrm{http}: / /$ www.mediamarket.ua/ (dostęp: 22.05.2015).

17 http://www.klik.ua/ (dostęp: 22.05.2015).

18 http://gamatehnika.com.ua/, http://www.terabit.in.ua/, http://tiptop.ua/, http://computer-ok. net/, http://mobimania.ua/computer/, http://ideal.lviv.ua/shop/groups.php, http://technopolis.net.ua/ computing, http://www.serviceplus.com.ua/, http://alfakom.com.ua/ua/, http://www.ozon.te.ua/, http://www.neotec.ua/, http://mkt.uz.ua/, http://www.slon.com.ua/catalog/, http://cyfromania.com. ua/, http://www.mstyle.if.ua/PC/, http://enter.com.ua/, deshevshe.ua/, http://220.if.ua/, http://bimbam.com.ua/, http://bomba.co.ua/, http://infomincer.net/, http://gigabyte.ucoz.ua/, http://laptopreview.org.ua/, http://kv-ua.net/, http://www.notebook.lviv.ua/ i in. (dostęp: 22.05.2015). 
lecz także bardzo do siebie podobne. Wygląd stron, których elementem obligatoryjnym jest oferta produktów IT, w zasadzie różni się jedynie zastosowanymi rozwiązaniami graficznymi, rozmieszczeniem poszczególnych elementów czy wykorzystaną gamą kolorystyczną.

Z asortymentem sklepów komputerowych klienci mogą zapoznać się w dwójnasób. Pierwszym, rzadziej już stosowanym sposobem jest umieszczenie na stronie wykazu produktów najczęściej w formacie .xls lub odpowiednio zarchiwizowanym pliku excelowskim (.rar lub .zip). Zdecydowanie częściej spotykany jest jednak klasyczny, dostępny na stronie głównej sklepu, niekiedy animowany (np. na stronie www.ozon.te.ua) wykaz towarów podzielony na odpowiednie kategorie produktów. Pierwszy z opisanych wariantów proponowany jest m.in. przez sklepy Terra $^{19}$ сzy Технополіс ${ }^{20}$, drugi zaś obowiązuje m.in. na witrynach sklepów $K_{T C}{ }^{21}$, Сервіс $^{+22}$ czy Idea ${ }^{23}$. Oba sposoby prezentacji asortymentu są do siebie zbliżone (w jednym i drugim nazwy poszczególnych produktów umieszczane są w pewnych zbiorach, według np. klucza nazw producentów lub kategorii produktów). Inny jest jedynie dostęp do nich — bezpośredni, poprzez stronę www lub pośredni, poprzez podpięty plik z odpowiednią zawartością.

Strona główna jednego ze sklepów ${ }^{24}$ zajmujących się sprzedażą produktów informatycznych prezentuje standardową strukturę przypisywaną do tego typu oferty. Elementem obligatoryjnym jest wykaz grup produktów, na tej akurat stronie umieszczony po lewej stronie - w kolejności: ноутбуки, планшети, монітори, комплектуючі, Wеb-камери, акустика, мишки, витратні матеріали, багатофункиіональні пристрої, зовнішні накопичувачі, мережеве обладнання. Pozostałe z wymienionych sklepów proponują niemal identyczne kategorie produktów, a różnice między nimi są niewielkie (wykaz kategorii np. w postaci paska poziomego może znajdować się u góry ${ }^{25}$ ekranu, a prócz wymienionych nazw można jeszcze zetknąc się z następującymi grupami produktów: комn'ютерна периферія, програмне забезпечення, друк та сканування, карти пам'яті та картрідери, клавіатури, прочесори і іп.).

Już same nazwy poszczególnych kategorii wprowadzają klienta w świat terminologii informatycznej. W większości są one niemal powszechnie znane, od lat funkcjonują bowiem w ramach języka ogólnego. Jednak zapoznając się szczegółowo z każdą z wymienionych kategorii, można natknąć się na nazwy, które nieobce są jedynie wąskiej grupie fascynatów najnowszych technologii.

$19 \mathrm{http} / /$ www.terra.rv.ua/index.php?option=com_content\&view=article\&id=77\&Itemid=110 (dostęp: 8.05.2015).

20 http://technopolis.net.ua/price/ (dostęp: 22.05.2015).

$21 \mathrm{http} / / / w w w . k t c-u a . c o m /($ dostęp: 8.05.2015).

$22 \mathrm{http} / / /$ www.serviceplus.com.ua/ (dostęp: 22.05.2015).

23 http://ideal.lviv.ua/shop/groups.php (dostęp: 24.05.2015).

$24 \mathrm{http} / / /$ gamatehnika.com.ua/ (dostęp: 24.05.2015).

$25 \mathrm{http}: / /$ www.ktc-ua.com/catalog/pc (dostęp: 24.05.2015). 
Poniżej przedstawiono wykaz poszczególnych kategorii oraz nazw produktów $^{26} \mathrm{z}$ dziedziny IT, w ramach tychże kategorii funkcjonujących. $\mathrm{Z}$ racji zdecydowanie bardziej szczegółowej ${ }^{27}$ prezentacji oferowanych produktów w cennikach .xls to właśnie jeden $\mathrm{z}$ nich ${ }^{28}$ (niekoniecznie najobszerniejszy, jednak charakterystyczny dla tego sposobu komunikowania się sprzedawcy z klientem) będzie stanowić bazę do dalszych rozważań w niniejszym artykule. Wyekscerpowane elementy słownictwa informatycznego, które reprezentują przede wszystkim obszar pojęć związanych z budową komputerów i urządzeń peryferyjnych, stanowią jedynie fragment pewnej całości. Są one jednakże pojęciami na tyle ważnymi, że nie może bez nich istnieć żaden tekst poświęcony zagadnieniom związanym z IT czy też kwestiami „okołoinformatycznymi”. Cenniki zawierające nazwy produktów informatycznych z racji pełnienia (w pewnym zakresie) również funkcji informacyjnej mogą być doskonałym źródłem materiału leksykalnego dla badaczy zajmujących się kwestiami terminologii, zwłaszcza zaś dla terminologów parających się problematyką słownictwa informatycznego. Ich wagi dla badań terminologicznych nie umniejsza nawet fakt, iż w wybranym do analizy wykazie znalazły się również formy niepoprawne pod względem ortografii i gramatyki, a także ewidentne rusycyzmy; jest to swego rodzaju zła „,norma” obecna nie tylko w tego rodzaju tekstach, ale i niemal całych ukraińskich zasobach internetowych.

\section{1. Портативні комп'ютери ${ }^{29}$}

Ноутбуки

Ноутбук Lenovo IdeaPad G500G 15.6» (1366x768) HD LED, гляни / Intel Celeron 1005M $(1.9 \Gamma)$

\section{Планшети}

Планшет Acer W1-810-17HK 8» IPS (1280x800), ємнісний Multi-Touch, Intel Atom Z3735G Аксесуари

Захисна плівка DIGI Screen Protector AR для Samsung Galaxy Tab3 10»

Блок живлення Miotex (MT54CH), універсальний для ноутбуків, вхідна напруга 110-240V Зарядний пристрій Trust Wall charger с 5 USB-портами Black

Кронштейн автомобільний під планшет Trust Universal Car Headrest Holder for tablets Підставка до ноутбука TRUST Frio laptopcooling stand with big fan

Стилус Trust Pen срібний

${ }^{26}$ Na nazwy wielu produktów IT składają się ciągi liczb i symboli, np. модуль nам'яmi DDR SDRAM 256Mb 133MHz, Hynix, PC-133, CL2.5, nie wnoszące niczego do rozważań językoznawczych.

27 Wykaz umieszczany w pliku .xls ma tę przewagę, iż może być o wiele bardziej szczegółowy; wykazy te, prócz podziału na kategorie, zwykle układane są alfabetycznie. Wprawdzie opisy produktów prezentowane bezpośrednio na stronach www są atrakcyjniejsze, częstokroć opatrzone zdjęciami, jednak wyszukanie konkretnego modelu może być nieco bardziej uciążliwe.

28 Plik pobrano ze strony http://mkt.uz.ua/ i opracowano dla potrzeb niniejszego artykułu.

29 Zapis materiału ilustracyjnego jest oryginalny. Przykłady, które umieściłem w obrębie poszczególnych kategorii, są reprezentatywne dla większej liczby propozycji zamieszczonych przez sprzedawcę, np. kategorii Ноутбуки przypisałem jeden przykład, podczas gdy w wykazie były 24 produkty, jednakże różnice między nimi przejawiały się jedynie w ciągach cyfr i symboli, dlatego też przytaczanie ich wszystkich uznałem za niecelowe. 


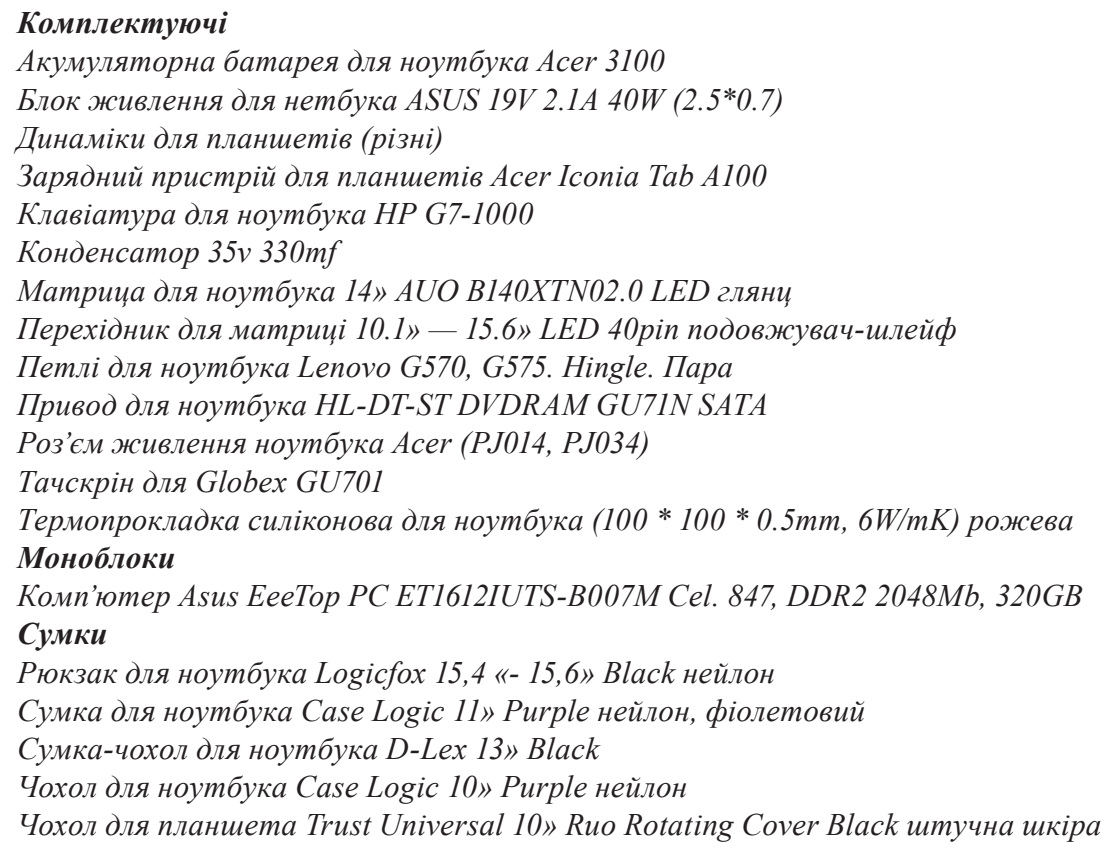

W kategorii Портативні комп'ютери 'komputery przenośne' znalazły się nie tylko laptopy, lecz także tablety (планшети), akcesoria do nich (аксесуари), podzespoły (комплектуючi), torby i futerały na tablety (сумки) oraz komputery stacjonarne (tu mamy pewną niekonsekwencję sprzedawcy), czyli popularne „pecety” (моноблоки). W obrębie tego zbioru nazw (uwaga ta dotyczy również pozostałych produktów w przedstawionych niżej kategoriach) mogłyby pojawić się jeszcze pojęcia takie jak виробник 'producent', проиесор (тактова частота) 'procesor (taktowanie)', оперативна пам'ять 'pamięć RAM', дисплей (роздільна здатність) 'ekran (rozdzielczość)' i in., które objaśniałyby zamieszczane ciągi liczb i symboli. Odczytując nazwy poszczególnych produktów należy zwrócić uwagę na ich zapis; niejednokrotnie klient natknie się bowiem na język rosyjski / nieznajomość ukraińskiej ortografii, np. Trust Wall charger с 5 USB-nортами; матрица для ноутбука czy paralelne formy np. przyimków, np. чохол для планшета - чохол до планшета.

\section{2. Комплектуючі}

\section{Процесори}

Проиесор Intel Pentium G3240 s1150, 2 ядра, 3.10GHz, 5200MHz

охолоджувачі

Вентилятор для корпусу CoolerMaster R4-SPS-20AK-GP 80*80*15мм, Sleeve, 3pin Кулер Maxtron для корпуса 40x40x25мм SB 2500 об/хв 25дБ Зріп чорний

Кулер до відеокарти Dеерсооl V50 3400 об/хв, 20 дб, алюміній

Кулер до корпусу Akasa APACHE Black 120*120*25мм, HDB, 600 - 1300RPM, 6.9-16.05 дБ Кулер до процесора Dеерсооl до AMD, sFM1, sAM3, sAM2, s754, s939, алюміній, 2800 об/хв Охолоджувач для HDD Revoltec подвійний (RS031)

Tермопаста CollerMaster набір шаблонів SC102 (шприи+шаблони), 4.0 2 


\section{Материнські плати}

Материнська плата ASUS H81M-K Socket 1150, Intel H81M, DDR3, 16GB, Realtek RTL8111G 10/100/1000 Mb/s

Maтеринская плата ELITEGROUP H61 H61H2-MV (Gigalan, HDMI) Socket 1155, DDR3 DIMM (1600/1333/1066 MH

\section{Оперативна пам'ять}

Модуль пам'яті DDR2 2048Mb Exceleram (E20101A / E20101B) 800MHz, PC6400, CL5, $(5-5-5-15)$

\section{Оптичні приводи}

Зовнішній оптичний накопичувач Transcend DVD $\pm R W$ TS8XDVDRW-W External USB 2.0 White

Накопичувач $D V D \pm R W$ для ноутбука $S A T A$

Вінчестери

Зовнішній накопичувач HDD 2.5» 1TB Silicon Power Stream S03 Black, USB 3.0

Накопичувач HDD 2000GB WD 5400-7200 об/хв, 64 MB, SATA III, Caviar Green

Відеокарти

Biдеокарта GeForce GT630 4096Mb ASUS DDR III, 810Mhz/1100MHz, 128 Bit, активне, PCI-Ex

Kopnycu

Kopnyc Frime 102BS Miditower, 400Bm, 2xUSB 2.0, безгвинтова зборка, чорний

Kopnyc Logicpower S602BS Slim, Mini-ITX, 400Bm, Audio, кард-рідер, чорно-сріблястий

\section{Блоки живлення}

Блок живлення Spire 420W ATX1.3, 1fan, 8cм, пасивна PFC

Звукові карти

Звукова плата ASUS XONAR PCI-Ex, 6 каналів (5.1)

Dział z podzespołami komputerowymi (комплектуючi) zawiera kilka grup produktów: проиесори 'procesory', охолоджувачі 'wentylatory', материнські плати 'płyty główne', оперативна пам'ять 'pamięć RAM', оптичні приводи 'napędy optyczne', вінчестери 'dyski twarde', відеокарти 'karty graficzne', корпуса 'obudowy', блоки живлення 'zasilacze', звукові карти 'karty dźwiękowe'. Uwagę zwracają synonimiczne nazwy elementów chłodzących (вентилятор, кулер, охолоджувач), „zapożyczenia” z języka rosyjskiego (материнская плаma, корпуса) oraz jedynie dwa określenia na pojęcie 'twardy dysk' (вінчестер, накопичувач $H D D$ wobec funkcjonujących też жорсткий диск, твердий диск czy nawet pojęcia постійний запам'ятовувальний пристрій).

\section{3. Монітори}

Монітор LG 22EA53T-P 21.5»Wide, AH-IPS з LED підсвіткою, $1920 x 1080$ (Full HD), 16:9, 1000:1 Монітор LG 22MP57A-P 21.5» матовый, IPS, 1920x1080, 16:9, 1000:1, 250 кд/м2, $14 \mathrm{Mc}(G \& G), 178 / 178, V G A$

Język rosyjski okazuje się być stałym elementem rozpatrywanego (i nie tylko tego) wykazu produktów. Zamiast ukraińskiego матовий pojawił się tu rosyjski przymiotnik матовый. Niekiedy obok pojęcia монітор napotkać można, zapożyczony nie tak dawno z języka angielskiego, leksem дисплей.

\section{4. Акустика}

Акустична система GEMIX Mini чорний, пластик, 2.0, 2 × 3 Bm (RMS), живлення: USB Бездротовий адаптер GEMIX BT-10 Speaker Bluetooth Adapter 
Монодинамік Logitech Multumedia Speaker Z50 Gray

Портативний динамік Trust Urban Revolt Vybe Wireless Speaker

Dział Акустика to zbiór nazw obejmujący elementy „dźwiękotwórcze”, głównie głośniki lub ich zestawy. Powinny się tu znaleźć również inne nazwy związane z emisją dźwięku, a więc ujęte w odrębnej kategorii Мультимедія — навушники 'słuchawki' і мікрофони 'mikrofony'.

\section{5. Клавіатури}

Клавіатура A4-tech (TK-7) темно-сіра, числова, USB

Клавіатура A4-tech KD-600L, чорна, мультимедійна, дротова, USB

Клавіатура Genius LuхеPad 9000 біла, класична, бездротова, Bluetooth

Комплект Trust Nola Wireless, чорний, оптична, клавіатура, мишка, USB, вологостійка

\section{6. Миші}

Мишка A4-tech (X-710MK) оптична, 2000 dpi, $16 \mathrm{~Kb}$, USB, BOX, кнопка «3x пострілу», чорна

Мишка A4-tech X-718BK black чорна, оптична, 3200 dpi, 16 Kb, дротова, USB, BOX, кнопка «потрійного пострілу»

Мишка Genius NetScroll 200 Laser, чорна, стандарт, лазерна, 1600 dpi, дротова, USB

Мишка Logitech Cordless M185 red, стандарт, оптична, бездротова (радіо), USB-нано Мишка Logitech Cordless M325 Nature Jewelry, синя з квітами, міні, оптична, 1000 dpi

Z racji swej różnorodności produkty oferowane w działach Клавiатури і Мumi opatrywane są o wiele bogatszymi komentarzami w języku ukraińskim niźli wcześniej wymienione elementy. Dominują tu zwłaszcza przymiotniki określające sposób przyłączenia urządzenia do komputera (дротова, бездротова, оптична), kolor (темно-сіра, чорна, синя з квітами), rozmiar (міні) czy szczególne cechy produktu (мультимедійна, вологостійка, кнопка «3x пострілу», лазерна).

\section{7. Килимки}

Килимок A4-Tесh ігровий, резинова основа, поверхня з тканини (250x2000х3мм)

Килимок A4-tech Bloody B-072 чорний з малюнком

Podkładki pod myszy w wielu sklepach komputerowych znajdują miejsce raczej w dziale akcesoriów. Są to elementy, które podobnie jak myszy komputerowe czy pendrive'y (punkt 14), często podlegają zabiegom mającym na celu indywidualizację produktu, stąd stosunkowo wiele określeń opisujących ich wygląd (поверхня з тканини, чорний з малюнком).

\section{8. Принтери}

Принтер Canon LBP-6020B лазерна, монохромна, A4, A5, B4, B5, $2400 x 600$ dpi, 18 чб. cmop/x

Принтер Canon Pixта іP2700 струменевий (4 кол.), A4, A5, B4, B5, 4800x1200 dpi, 22 чб. c/x

Leksemowi принтер (czasem można też spotkać nazwę друкарка ${ }^{30}$ ) towarzyszą pojęcia opisujące budowę i funkcje tego urządzenia. Podobną charaktery-

$30 \mathrm{http} / /$ xmapa.com.ua/shop/category/kompiuteri-i-orgtehnika/ortehnika/printeri-kopiri-mfu\# (dostęp: 28.05.2015). 
styką cechują się również urządzenia wielofunkcyjne przedstawione w kolejnym punkcie (Багатофункціональні пристрої). Wśród ciągu symboli znajdują się przymiotniki zarówno wskazujące na funkcje danego modelu, np. струменевий, кольоровий, лазерна, монохромна (rodzaj dwóch ostatnich przymiotników wskazuje, iż autor wpisu miał na myśli raczej leksem друкарка aniżeli принтер), jak i rzeczowniki określające rodzaj urządzenia, np. Принтер-копір-сканер.

\section{9. Багатофункціональні пристрої}

БФП Canon i-SENSYS MF4730 принтер-копір-кол. сканер, лазерна, монохромна, A4

БФП Canon РІХМА Е464 принтер-копір-сканер, струменевий, кольоровий, A4, $4800 \times 600 \mathrm{dpi}$

\section{0. Мультимедія}

Вебкамери

Веб-камера Trust SpotLight Webcam відео до 640x480, фото до 0.3 Мрх, мікрофон

Ігрові маніпулятори

Геймnad Trust GXT-530 gamepad for pc\&ps, USB

Руль Genius Speed Wheel 3 MT

\section{Мікрофони}

Мікрофон Trust Talkeе mini настільний

Навушники

Гарнітура Trust eeWave S20 Wireless Headset бездротова

Навушники Sony MDR-E9AD Orange

ТВ-тюнери

TB тюнер Trimax TR-2012HD PLUS зовнішній незалежний, ичифровий DVB-T2, 1920x1200, без $F M$

W kategorii Мультимедія znalazło się pięć podkategorii produktów: Вебкамери, Ігрові маніпулятори, Мікрофони, Навушники оraz ТВ-тюнери. Na uwagę zasługuje tu pisownia, a w efekcie postać dwóch rodzajów produktów. W literaturze przedmiotu natknąc się można na następujące zapisy leksemów вебкамера (веб-камера, web-камера, вебкамера, камера, мережева камера) oraz TB-тюнер (тюнер ТВ/ФМ, ТВ/ФМ-тюнер, ТВ-тюнер, ТВ тюнер, ТВ програвач, TV/FM Тюнер, w tym formy angielskie TV/FM Tuner, TV-Tuner). Z kolei pośród kontrolerów do gier (Ігрові маніпулятори) brakuje niewątpliwie dwóch produktów: dżojstika (джойстик) oraz trackballa (трекбол).

\section{1. ББЖ}

Акумуляторна батарея X-Digital $12 B 9 A 4$

ББЖ Powercom WAR-400 A line interractive, $400 \mathrm{~B}^{*} \mathrm{~A}, 200 \mathrm{Bm}$

Стабілізатор напруги Powercom TCA-1200, 600Bm, ступенчатий

Abrewiatura ББЖ (блок безперебійного живлення, rzadziej пристрій безперебійного живлення, пристрій захисту від аварійних перепадів напруги) oznacza urządzenia przeznaczone do nieprzerwanego zasilania odbiorników elektrycznych, w języku polskim funkcjonujące jako UPS (ang. Uninterruptible Power Supply). W tym konkretnym przypadku termin ten jest określeniem całej grupy urządzeń, obejmujących też baterie (акумуляторна батарея) i stabilizatory nаріе̨сіа (стабілізатор напруги, регулятор напруги). 


\section{2. Флеш пам'ять}

Флеш карта microSD 16 Gb Class 10 Kingston (SDC10/16GB) + перехідник

USB флеш накопичувач 16 Gb Apacer Handy Steno AH323 black, 16 Gb, пластик, чорний

Kapmpidep GEMBIRD FDI2-ALLIN1-B, black, внутрішній 3.5»

\section{3. Носії інформації}

Бокс DVD-box 10DVD 33мм суперпрозорий

Диск DVD+RW 4,7Gb Philips $4 x$ Cake 10 pcs

Дискети FDD Verbatim 1.44MB Datalife 10um Paper box

Конверт для $C D$ з віконием, 100шт./уn.

Маркер AXENT DELTA CD/DVD D2700, 0.7 мм чорний

Miнi диск DVD-RW 1,4Gb Verbatim 2x Printable Cake 10 pcs

Optyczne nośniki informacji prezentowane w tym punkcie (диски, дискети, міні-диски), a także akcesoria do nich (бокси, конверти, маркери) орisywane są głównie za pomocą informacji w języku angielskim; nieliczne określenia w języku ukraińskim (суперпрозорий, з віконцем, чорний) dotyczą głównie akcesoriów.

\section{4. Аксесуари}

Aдanmep micro USB Lightning iPhone 5, iPad 4 Mini

Блок живлення до TP-Link

Зарядний пристрій USB iPhone iPod кубик

Інвертор автомобільний Titan HW-150E6 (вхідна напруга: 12B, вихідна напруга: 230B $\pm 5 \%$ )

Кабель USB2.0 А-B до принтера $4.5 \mathrm{~m}$

Кабель USB2.0 подовжувач $1.8 \mathrm{~m}$

Кабель HDMI A to HDMI C (mini) Viewcon 1.8 м, v1.3b, золотисті конектори

Кабель монітора 1.8м DVI-DVI (24+1) 2 фільтра, позолота, чорний

Кабель сигнальний VGA HD15M/HD15M 3m з 2-ма феритами

Кабель аудіо S/PDIF 1.5м Toslink квадратний

Кабель USB до іPhoпе 5, якісний (металева оплітка)

Кабель живлення для аудіо-відео техніки, 1,8 м (восьмерка)

Карман зовнішній SDD 14мм

Конвертор USB to PS/2 GEMBIRD

Кріплення для установки 2.5» SSD в 3.5» відсік Kingston

Наклейки для клавіатури (непрозорі:UA,RU) срібні, кирилиия

Перетворювач живлення для авто прикурювача Gembird

Перехідник живлення USA > EURO розетку (із заземленням)

Подовжувач Aиdio DC3.5 тато-мама 1.2м Gold

Стяжки для кабеля $3.0 \times 100 \mathrm{~mm} 100 \mathrm{~mm}$

Шлейф даних SATA

Шлейф живл.: перех. на SATA (Molex)

Zarówno akcesoria komputerowe (аксесуари), jak i materiały eksploatacyjne (витратні матеріали) stanowią obok działu z podzespołami komputerowymi (комплектуючi) jedną z najliczniej reprezentowanych grup produktów. Ich różnorodność, począwszy od kabli (кабель FireWire, кабель DVI to DVI, кабель сигнальний VGA i in.), taśm (шлейф даних SATA, шлейф 6-канальний для СБПЧ), tzw. przejściówek (перехідник DVI-A 24pin to VGA 15pin, перехідник живлення ATX 4P Male -> 8P Female), poprzez naklejki na klawiaturę (наклейки для клавіатури), kieszenie na dyski (карман зовнішній SDD), kartridże (картридж Arrow 
CANON Pixma, картрідж для СБПЧ EPSON), tusze (чорнило ColorWay), po wałki magnetyczne (вал магнітний НР) i bębny światłoczułe (фотобарабан $H P)$, jest naprawdę imponująca. Większość terminów znajdujących się w obu grupach produktów to proste (блок живлення, кабель монітора, карман зовнішній, чіп картриджа itd.) oraz złożone skupienia imienne (кабель живлення для аудіо-відео техніки, гальмівна площадка картриджа, картрідж для перезаправних комплектів, контактна площадка картриджа itd.). Znamienne dla opisywanego źródła są nie tylko elementy rosyjskiej fleksji (тонера — mianownik Im.) czy niekonsekwencja w pisowni (картридж - картрідж, чип - чіn), ale i ogromna liczba zapożyczeń (інвертор, шлейф, кабель, конвертор, драм-картридж, конектор, девелопер і іn.).

\section{5. Інтерфейсні плати}

USB 4-портовый Хаб TRUST Curve USB 3.0

Adanmep Trust USB 3.0 Bluetooth

Конвертор USB to COM ST-Lab USB 2.0, 1хCOM, кабель 1.5м

Контролер STLab U-165 USB 2.04 канала (3 зовн.+1 внутр.)

W kategorii Інтерфейсні плати 'karty interfejsu sieciowego' znalazły się urządzenia komunikacyjne (хаб, контролер). Jak wspomniano wyżej, już jako swego rodzaju „normę” należy traktować obecność form wywodzących się z języka rosyjskiego (4-портовый, 4 канала).

Zaprezentowane przykłady stanowią jedynie część nazw, które funkcjonują w obrębie witryn sklepów zajmujących się sprzedażą produktów IT $^{31}$. Każda z nich posiada swą specyfikę, co pośrednio wpływa na zakres oraz przekrój oferowanych towarów, a co za tym idzie również na ich stronę językową.

Przedstawione kategorie produktów z dziedziny IT, a także ich konkretne nazwy niejednokrotnie wzbogacone dodatkowymi informacjami i komentarzami, które również niosą z sobą bagaż znaczeń informatycznych, stanowią jedynie pewien wycinek słownictwa funkcjonujący w ramach ukraińskiej terminologii informatycznej. Prezentowane przykłady nazw związanych z budową komputera, jego podzespołami bazowymi, akcesoriami, urządzeniami sieciowymi itd. funkcjonujące w obrębie witryny mkt.uz.ua są interesujące pod wieloma względami. Wśród najważniejszych wymienić należy przede wszystkim to, iż są one doskonałym materiałem faktograficznym, który można wykorzystać zarówno w pracach o charakterze terminologicznym, jak i leksykograficznym czy poprawnościowym. Słownictwo obecne na tego rodzaju witrynach w wielu przypadkach nie funkcjonuje $\mathrm{w}$ żadnych słownikach, a nie zostało skodyfikowane z prostej przyczyny — jest ono ,produktem” niezwykle dynamicznych procesów twórczych w obrębie jednej z najprężniej rozwijających się dziś dziedzin nauki, zaś działania związane

31 Ze względu na ograniczenia wydawnicze pominąłem omówienie następujących grup produktów: витратні матеріали, засоби для чистки оргтехніки, мережеве обладнання, програмне забезпечення, проектори. 
z ułożeniem słownika, zwłaszcza słownika terminologicznego, wymagają zaangażowania wielu specjalistów, a przede wszystkim - czasu.

Wspomnianej dynamice, która wiąże się do pewnego stopnia z chaosem twórczym, towarzyszą efekty niepożądane: niestabilność w obrębie pisowni ukraińskiej (zapisy poszczególnych pojęć niezgodne z regułami ukraińskiej ortografii), nadmierna obecność anglicyzmów i rusycyzmów (czy wręcz form graficznych bezpośrednio przeniesionych $\mathrm{z}$ tych języków, co destabilizuje w istotny sposób recepcję informacji) oraz zbyt duża fluktuacja w obrębie tego słownictwa czy występowanie podwójnego, a niekiedy potrójnego nazewnictwa, co stoi w sprzeczności z zasadą jednoznaczności terminów.

Nie ulega wątpliwości, że ukraińskojęzyczne witryny sklepów komputerowych są ważnym źródłem terminologii informatycznej. Ich obecność, a przede wszystkim nasycenie terminologią IT, wpływa pozytywnie nie tylko na umocnienie pozycji ukraińskiego słownictwa związanego z najnowszymi technologiami, na popularyzację analizowanych zasobów leksykalnych, ale także w pewnym stopniu na modyfikowanie pojęć już istniejących i kreowanie nowych. $\mathrm{Z}$ uwagi na ciągłe zmiany zachodzące nie tylko w obrębie opisywanego słownictwa, ale i poziomie językowym samych sklepów oferujących produkty IT, należy zwrócić na nie baczniejszą uwagę. Zaowocuje to przybliżeniem tego niedocenianego jak dotąd źródła leksyki, a w konsekwencji większą liczbą opracowań naukowych dotyczących ukraińskiego słownictwa informatycznego.

\section{Bibliografia}

Encyklopedia językoznawstwa ogólnego, red. K. Polański, Wrocław-Warszawa-Kraków 1995.

Jóźwikiewicz P., Pochodzenie, budowa i funkcjonowanie ukraińskich nazw podzespołów komputerowych, „Studia Ukrainica Posnaniensia” 2013a, z. 1.

Jóźwikiewicz P., Lingua Ucraina ad res informaticas pertinens. Studium nad ukraińskim stownictwem informatycznym, Wrocław $2013 \mathrm{~b}$.

Jóźwikiewicz P., Ukraińskie stowniki terminologii informatycznej (1990-2010), „Slavica Wratislaviensia" CLIX, Wrocław 2014.

Григорович I.I., Порівняльний аналіз термінологї̈ програмних продуктів фірми Майкрософт в англійській та украӥнській мовах, „Науковий вісник Волинського державного університету ім. Л. Українки” 2007, № 4.

Зимовець Г., Структурно-прагматичні характеристики жанру інтернет-сайту, „Лінгвістика XXI століття: нові дослідження і перспективи" 2009, № 3.

Іваненко Л., Первісток обчислювальної техніки. До 60-річчя створення МЕСМ, „Вісник НАН України” 2011, № 12.

Кубайчук В.П., Мейнарович С.В., До пакету Windows Ukrainian Interface Pack, http://tc.terminology.lp.edu.ua/TK_sem_WinUA.htm\#Sect1.

Недюха М., Інтернет як засіб форорування інформаційної культури, http://archive.nndiuvi. org.ua/fulltext.html?id=916. 
Онищенко Ю.К., Порівняльний термінологічний аналіз перекладів украӥнізованих програм компанії «Майкрософт»», „Гуманітарний вісник. Серія: Іноземна філологія” ч. 12, т. 1, Проблеми сучасної світової літератури. Проблеми сучасного перекладознавства, Черкаси 2008.

Пиріг С.О., Дослідження ринку електронної комериії в Україні, „Економічні науки. Серія «Облік і фінанси»" 2014, 11 (41).

Рожанківський Р., Інформаційна мова та інформаційні терміни програмного продукту Ворд компанії Майкрософт, „Збірник наукових праць учасників 8-ї Міжнародної наукової конференції «Проблеми української термінології СловоСвіт 2004»”, Львів 2004.

Рудик М., Українське слово в Інтернеті, http://journ.lnu.edu.ua/publications/zbirnyk07/ Zbirnyk07_Rudyk.htm.

Симоненко О., 3 історії становлення та розвитку терміносистеми інформаційних систем i технологій, [w:] Українська термінологія і сучасність, Відп. ред. В.Л.Іващенко, Київ 2003, s. 169-174.

Стишов О., Особливості розвитку лексичного складу української мови кіния XX cm., "Мовознавство" 1999, № 1.

Стрельбіцька Л., Інтернет як полігон розвитку природної мови, „Вісник Нац. ун-ту »Львівська політехнікащ. Проблеми української термінології” 2005, № 538.

Федорів М.Л., Про особливості комп'ютерного дискурсу, „Наукові записки НУКМА” 2003, ч. I.

Хоменко Л.Г., История отечественной кибернетики и информатики, Києв 1998.

Хоменко Л.Г., Історія вітчизняної кібернетики та інформатики, Автореф. дис. д-ра іст. наук: 07.00.07, Київ 2000.

Щур I.I., Особливості украӥнського комп'ютерного жаргону, “Рідна школа” 2001, №3.

Щур I.I., Внутрішня форма одиниць комп'ютерного сленгу, [w:] Актуальні проблеми украӥнської лінгвістики: Теорія і практика, Ред. Л.І. Шевченко, 2003, Вип. 7.

Щур I.I., Комп'ютерний сленг (на матеріалі найменувань складових комп'ютера), [w:] Мовні i кониептуальні картини світу: 3б. наукових праць, Ред. О.І. Чередниченко, Вип. 11, Кн. 2, Київ 2004a.

Щур I.І., Комп'ютерний сленг у функиіональному аспекті, [w:] Мовні і концептуальні картини світу: 3б. наук. пращъь. Ред. О.І. Чередниченко, Вип. 14, Кн. 2, Київ $2004 b$.

\section{Websites of computer stores as a source of ukrainian IT vocabulary}

\section{Summary}

Ukrainian e-commerce develops very dynamically. Shops selling electronic devices, in particular IT products, dominate this market. In his article the author draws attention to the fact that the Internet websites of such shops are a rich source of Ukrainian IT vocabulary. The survey of the lexicon used on one of such websites is to prove the essential role those lexical items play in importing and creating the lexicon within this language subsystem.

Keywords: the Ukrainian language, IT lexicon, hardware, computer shop pricing list. 


\section{Інтернет-сторінки магазинів комп’ютерної техніки як джерело української комп’ютерної лексики}

Rезюме

Ринок електронної комерції розвивається в Україні дуже динамічно; одними з найбільших гравців цього ринку є магазини, яких спеціалізація - продаж електроніки, зокрема комп'ютерної техніки. У статті доказано, що інтернет-сторінки таких магазинів $€$ важливим джерелом української комп'ютерної лексики. Огляд лексики, що виступає на сайті одного з магазинів мав бути доказом значної ролі, яку вони відіграють у процесі імпортування, засвоєння та творення термінів в рамках цієї мовної системи.

Ключові слова: українська мова, комп'ютерна лексика, хардвер, прайс-листи комп’ютерних магазинів. 